Two grants have been made for statistical evaluation of eloud-seeding experiments. J. Neyman of the University of California at Berkeley will direct a group in the Statistical Laboratory on randomized cloud-seeding experiment under a two-year grant of 64,900 dollars. Such experiments have been conducted for two years in Santa Barbara and Ventura counties, and will be continued. The data available will be subjected to statistical scrutiny independent of any a priori hypotheses concerning the distribution of rainfall, using non-parametric statistical methods with the aid of a high-speed computer.

Max A. Woodbury of the Department of Mathematics, New York University, will make a two-year study of the statistical evaluation of weather modification with a grant of 58,800 dollars.

Three grants in support of conferences have also been made. The American Geophysical Union has received 25,000 dollars for a conference on "Mechanisms of Precipitation Formation". The National Academy of Sciences-National Research Council has received 10,000 dollars for a conference on the "Design and Conduct of Research Programmes in Weather Modification", under the direction of S. S. Wilks of the Division of Mathematics. The Foundation for Instrumentation Education and Research received 5,100 dollars for a conference on "Instrumentation for Cloud and Weather Modification".

\title{
PERSONNEL MANAGEMENT IN PERSPECTIVE
}

$\mathrm{A}^{\mathrm{N}}$ $\mathrm{N}$ inquiry into the reasons why modern personnel management is experiencing a crisis in its development, and why it is not producing better work through happier employees, has recently been made by Col. L. Urwick*. The major weakness in modern personnel management is, he suggests, its lack of integration into the organizational structure of businesses. There are many historical reasons for this trend and it needs urgent remedying. The corrective needs to be introduced at the very top of industry, by the leaders of business themselves.

The final strength of a business is no more than the collective strength of the individuals composing it. This has been known for years and in the past two decades business has invested millions of pounds in various schemes of personnel management. The expected results have not been achieved. The workforce remains obstinately unmoved, and management itself has its doubts. One reason is that business still looks on its employees as 'economic men' seeking exclusively economic objectives, whereas in reality social objectives are more important to most employees. Another reason is that employees are seen as individuals and not as members of a social group. The effort of personnel management is not directed towards achieving high morale through the social group. The test of a good personnel policy is high

* Institute of Personnel Management. Occasional Papers, No. 13 : Personnel Management in Perspective-Suggestions on the Correct Place of Personnel Activities in Business Organization. By L. Urwick.
Pp. 23. (London: Institute of Personnel Management, 1959.) 4s. morale, a matter not so much of doing things materially for employees, as of stimulating them to achieve something together. High morale requires, above all, leadership from the chief of the enterprise.

Historical trends have weakened the leadership content in personnel management. Personnel activities have become something 'tacked on to' a business because of the need for specialization, and this has prevented the personnel officer from obtaining the authority which should have accompanied his specialized responsibility. The solution is to make the 'line' manager at every level more directly responsible for personnel activities, using the personnel officer more fully for advice.

'Line' managers, especially at the heads of businesses, have found themselves overloaded in attempting to discharge their personnel responsibilities. The solution is to develop the use of general staff officers who can relieve their chiefs of details in all their functions. The possibilities here have long been understood by the Armed Services but are still not exploited in business.

Personnel management has suffered from the growing pains of the new kind of management, which acknowledges a much greater social responsibility, but is fitful in its efforts to shoulder the new burdens. Personnel men were given sometimes too much authority, sometimes too little. The solution is patient, sustained and prudent effort over many years by business leaders to get a personnel policy working well within their organization.

\section{HAMATOLOGY}

\begin{abstract}
A NUMBER of the British Medical Bulletin (15, No. 1 ; 1959) has attempted to review some of the many important advances that have been made in hrmatology in the past few years. This, in a series of fourteen articles, the contributors have done in a most stimulating and readable manner. The subject-matter covered includes the deficiency anæmias, the chemistry of normal and abnormal hæmoglobins and their inheritance, hæmolytic anæmias, the leukæmias, the life-history of the lymphocytes and bone marrow culture.

Many of these reviews are particularly stimulating. The description of the life-history of the lymphocytes, cells which hitherto have been somewhat mysterious cells, shows that the usual concepts of their life within the body must be reconsidered.
\end{abstract}

Normal hæmoglobin synthesis is presented in contrast to a description of the chemistry of the abnormal hæmoglobins. Modern methods of electrophoresis and chromatography have shown that the sole difference between normal adult and sickle-cell hremoglobin lies in the substitution of one aminoacid for another in one of their constituent peptides. Similarly, the exact defects in other abnormal hæmoglobins are being elucidated.

The alterations of red cell structure in other forms of hæmolytic anæmias are described where (either due to inherited or acquired defects) chemical changes in the lipoid, protein, glutathione or glycolytic systems can be demonstrated. Other aspects of the hæmolytic mechanisms are covered by reviews of the latest modifications in our knowledge of the 